\title{
OPINIÃO COMO RETÓRICA
}

\section{Denise das Neves Barbosa de Souza}

RESUMO: Este trabalho trata da análise das páginas opiniáticas existentes nos jornais majoritários do País, com ênfase na página 7 Opinião, do jornal O Globo -, do ponto de vista (i) da correspondência significante existente entre a formatação desta página e a de outras similares e de menor porte no âmbito do próprio jornal; (ii) do recorte teórico-analítico que privilegia o aspecto formal do signo para a inteligibilidade da página enquanto narração de uma história de poder que coincide com a história das relações simbióticas entre as empresas jornalísticas e os poderes constituídos. Nesse percurso, foram analisados fatos e personalidades relevantes da história da imprensa nacional e todos os artigos que compuseram um determinado período em que a composição da página manteve-se com padrão estrutural fixo, à luz da Semiótica proposta por Roland Barthes e Umberto Eco.

Palavras-chave: Semiótica discursiva, retórica midiática, discurso do poder, simulacro da democracia, sentido na formatação jornalística, opinião, supremacia do editorialismo

Introdução

As leituras que me acompanham desde a finalização do curso de graduação até a finalização dos créditos da Pós-Graduação, há muito tempo instigam o meu espírito no sentido de compreender até que ponto as teorias da e sobre a linguagem eram suficientes para desvelar o sentido de narrativas tão diferenciadas quanto um romance, uma crônica jornalística, ou simplesmente um texto informativo ou didático de qualquer jornal. Outro motivo instigador encontrava-se no fato de que os textos analisados tanto durante as aulas acadêmicas quanto em congressos e conferências teimavam em pontuar circunstancialmente assuntos neles contidos sem que tal resultado satisfizesse a minha curiosidade sobre o potencial de significação que ainda restava depois do silêncio. Assim é que, compreendendo que somente as orientações que

(*) Dissertação de Mestrado. Programa de Pós-Graduação em Letras da Universidade Federal Fluminense. Rio de Janeiro, 2003. 
extrapolassem o campo compartimentalizado dos estudos lingüísticos poderiam me auxiliar, busquei em ciências afins subsídio para avançar na decifração e na decodificação de narrativas, as mais diferenciadas, sabendo que, ainda assim, muito dos segredos que escondem as palavras que falam os homens permaneceriam indevassados.

Presa de um período histórico em que o acirramento das relações políticas e ideológicas transformava as leituras dos periódicos em matéria altamente estimulante para reflexão sobre os caminhos para aonde caminhava o ideário político nacional, passei a direcionar o foco do meu interesse analítico para as matérias jornalísticas relativas aos acontecimentos mais recentes da vida nacional, que passava por uma turbulência política em que pendulavam forças ideológicas diametralmente opostas. Impressionada com o dirigismo ideológico que grassava nas entranhas e nos interstícios dos cadernos que compõem quase todos os jornais, escolhi uma determinada página de um jornal de expressão nacional para centramento do meu trabalho analítico, a página Opinião, entendendo que ela poderia servir para a comprovação de hipótese acerca do dirigismo político ideológico acima mencionado. A partir daí, formatos jornalísticos semelhantes foram sendo amealhados e correlacionados para efeito de recorte do universo da matéria sob análise, bem como a história da existência dessa seção opiniática ao longo do desenvolvimento da imprensa brasileira.

Não foi espaçado o salto deste assunto em particular para uma breve incursão na história do desenvolvimento da imprensa brasileira, aí já com os subsídios necessários para verificar a hipótese de serem as relações de poder da mídia uma derivada inequívoca da própria história do poder constituído, segundo o que esses dois constituintes, governo e imprensa, conseguem manter uma relação de equilíbrio necessária à manutenção da ordem democrática.

Primeiro, rastrearam-se todos os significados de todos os artigos contidos na página Opinião do jornal $O$ Globo de sábado (entre 27/05/2000 e 11/05/2002), em seguida, estabeleceu-se uma análise das relações tipológicas e tipográficas para efeito da verificação da influência de sentido que essas formas carreavam para a internalização da significação da página total em si como um novo texto ela mesma. Em seguida, analisaram-se os mecanismos de formalização significante que comprovaram a hipótese de que os três articuladores (Luís Fernando Veríssimo, Olavo de Carvalho e 
Dom Eugênio Sales) das matérias inseridos na página Opinião configuravam, eles mesmos, o representamen do ideário empresarial que, utilizando-os como personagens de seu próprio texto soberano determinava os fios condutores de uma narrativa que privilegia a manutenção da hegemonia da própria voz empresarial/oficial.

\section{Pressupostos teóricos}

Os estudos linguiísticos, a partir da sua concentração, na segunda metade do século XIX, em ciência autônoma das Letras e das Humanidades, evidentemente, receberam os benefícios inerentes à autonomia e ao prestígio que as ciências "científicas" já desfrutavam, mas também o ônus da definição de seu objeto, da natureza de sua função e de sua correlação de forças com outras ciências similares, no caso as ditas ciências das Humanidades. Salvo melhor entendimento do assunto, essa problemática, passado mais de um século, continua a perturbar a ordem racional de quantos buscam compreender ainda hoje a especificidade de um objeto cuja capilaridade funcional perpassa naturalmente vários outros campos das ciências que guardam um parentesco com as questões lingüísticas. No entanto, um dos maiores benefícios dessa divisão classificatória foi, do nosso ponto de vista, ter propiciado o advento de ciências novas que, embora guardando reflexos da origem, avança no sentido de ampliar o escopo do objeto científico que esquadrinha a ciência lingüística.

Um toque de mestre na análise desta questão vem de Habermas [1998, p.35] na obra magistral, On the Pragmatics of Communication, em que sua reflexão crítica acerca das teorias lingüísticas até então surgida, aponta para o surgimento de uma teoria denominada Reconstrutivismo Lingüístico, cujo movimento de reversão pretende transformar o conhecimento de matérias competentes já suficientemente teorizadas em um conhecimento objetivo e explícito, de tal forma que fique claro em qual sentido dever-se-á utilizar a expressão análise "formal". Se era impossível refutar o movimento pragmático avassalador que varreu para o lixo da história linguiística o critério da objetividade como fundamento analítico de valor, vê-se agora um retorno à busca dessa objetividade perdida pelos braços, como não poderia deixar de ser, da Filosofia. Quiçá antecipando já os novos ventos intelectivos de influência neste novo século, já nem tão pós-moderno assim. 
Fala-se aqui, então, do berço dos estudos de linguagem não apenas como veículo de produção de sentido, mas da sua expressão mais ampla, qual seja, a de incluir a estruturação do pensamento na base mesma da construção da linguagem humana. Sem tratar especificamente dos desdobramentos das teorias da cognição que tangenciam a questão da inteligibilidade humana pelo prisma da consciência que tem o homem sobre o universo e si mesmo, é fato que o despertar dos estudos da linguagem induziu ao surgimento de parcerias de base científica variada, próximas umas, distantes outras, para a empreitada de compreensão mais bem acabada do fenômeno da linguagem humana. Não resta a menor dúvida de que a Filosofia, enquanto método reflexivo-analítico auxiliar do lingüístico, vem desempenhando papel fundamental nesse processo, uma vez que postula a idéia da representação (representamen) como imanência pura nas unidades do pensamento humano. Assim, tendo no pensamento a origem de todo o processo de significação, o objeto, o dado de realidade apreendido e representado por um sistema social (lingüístico) deverá ser compreendido em algum outro processo que não apenas o da representatividade lingüística, pois a esta pressupõe o mundo das idéias.

Tudo isto colabora para a naturalidade do nascimento da ciência Semiótica, parente próxima da Lingüística que pretende superá-la em abrangência e profundidade semântica pelo fato de buscar a razão do signo linguístico no constructo das idéias. Pela Filosofia, será talvez possível definir os parâmetros científicos sob os quais, supõe-se, será mais bem analisado este objeto renascido, denominado linguagem. Pode-se dizer, ainda, que se encontra nesse tipo de arrazoado uma diretriz para alguns filósofos que, fazendo tábula rasa dos métodos inovadores de apreensão do fenômeno lingüístico, como é o caso da contribuição da Semiótica nos dias atuais, atiram indiscriminadamente contra quem ouse denominar-se lingüista, assim sendo presa dos mesmos grilhões que aos outros ata. Falta-lhes, sem dúvida, o conhecimento de que o seu erro é de alvo: vêem no objeto lingüístico uma faculdade estática e circunscrita que, embora assim exista para registro de identificação das coisas do mundo e da realidade sensível visando à comunicação (noção de código e sistema), subsistem enquanto forma de uma outra ordem expressiva, anterior à própria concepção do objeto primeiro. 
Neste ponto, chega-se à definição do entendimento que se tem da metáfora e de sua escolha para o substrato analítico das páginas opiniáticas dos jornais - da página 7 do jornal O Globo, página Opinião -, não como uma figura de estilo, próxima do símbolo ou das onomatopéias, e sim como um processo estruturante de significação com privilégio das formas que, de resto, pré-existem às representações de fato da realidade e que se transformam elas mesmas em unidades significantes.

De acordo com Umberto Eco (1998, p. 332), a Semiótica deve ser compreendida como

uma filosofia das linguagens no sentido que a isto se propõe, não somente com relação às regras do èrgon, como também dos processos da enérgheia. Uma semiótica geral é uma filosofia das semiosis e encontra a semiose mesmo fora das trocas intencionais de informação: no âmago da natureza, para além das estruturas convencionais, nas relações codificadas, no próprio mecanismo do pensamento referenciado, na formulação de hipóteses ou no processo abdutivo" [Tradução nossa].

Não se pretendende aqui detalhar o sofisticado raciocínio de Eco acerca das categorias metodológicas tomadas de empréstimo a Peirce, ressalta-se, no entanto, sua importância para o subsídio da análise desenvolvida sobre as páginas opiniáticas da imprensa no Brasil.

Tanto o método dedutivo quanto o abdutivo (que trata da inferência por hipóteses) suportam os procedimentos analíticos adotados para o estudo da linguagem midiática em questão, sendo a ênfase no processo indutivo, ou mesmo nas inferências hipotéticas, suficiente para a apreensão de um sentido que paira além da representação expressa.

Corroborando as assertivas de Sugli Specchi ${ }^{1}$, o capítulo 2 do Tratado de Semiótica ${ }^{2}$ refere a abdução como um princípio que "não intervém apenas quando se interpreta uma mensagem referida a

In Tratado de Semiótica, 1976, p.120.

In Sugli Specchi, 1998. 
contextos ou circunstâncias não-codificadas, mas que serve também para individuar o código (ou o subcódigo) correto por uma mensagem imprecisa. Segundo ele,

a abdução, como qualquer outra interpretação de contextos e circunstâncias não codificadas, representa o primeiro passo de uma operação metalingüística destinada a enriquecer o código. Ela constitui o mais evidente exemplo de PRODUÇÃO DE FUNÇÃO SÍGNICA.

Do ponto de vista da inserção da metáfora enquanto elemento estruturante do pensamento, que produz a formalização mental para que as idéias tomem forma e, embora guardando sua individualidade semântica, insiram-se por força, num código viabilizador da comunicação da expressão, pode-se dizer que esse mecanismo lógico responde pelo primeiro movimento metalingüístico destinado a enriquecer o código convencional e formar um outro em que os contextos diversos são formalizados para a criação de uma linguagem determinada (como é o caso das páginas e dos jornais em questão), assim definindo-se como unidades, identidades representativas de significação.

No caso da hipótese formada para análise deste trabalho, a formatação das páginas, a inserção de determinados articulistas e da escolha do quantitativo numérico destas, a prevalência de sua atuação em determinado dia da semana, a duração calculada do seu contrato, a formatação da página sua manutenção apenas em período determinado, a relação histórica entre a origem da página estudada e o período político de seu nascimento e duração etc., constituem-se elementos formais de estruturação de um código próprio para a expressão de uma linguagem cuja interpretação será apenas apreensível pela conformação de um código lingüístico não linear e próprio.

Kittay (1987, p.156) reforça a importância desse mecanismo estruturador de códigos não lineares quando esclarece funcionar a metáfora como operador dessa codificação; como "aquele que fornece uma interpretação que resulta do mapeamento de algumas (não todas) relações de contraste e afinidade que o termo enfocado empresta para outros termos no seu próprio campo semântico e, daí, para uma parte do domínio conceitual de um campo semântico distinto do quadro 
metafórico o tópico da metáfora" - que bem reflete o caso analítico da simbiose dos poderes instituídos analisados nas 400 e poucas páginas deste trabalho.

De Roland Barthes foram assimiladas, dentre muitas outras, as lições sobre a formação de uma lógica significante para a apreensão do sentido segundo um modelo formal em que o processo de mutação dos significados faz-se pela substituição, em cadeia, dos significados para sua transformação em significantes novos, e assim por diante. Analisando a estrutura lingüística dos mitos, para ele uma narrativa como outra qualquer, Barthes, já em 1975, compreendia que a Lingüística necessitava de outras inferências de competência científica para conseguir definir o seu objeto e, assim, adquirir o status de ciência. A idéia de que a Semiótica era já uma ciência mais avançada, com relação 'ao estágio mais avançado de definição do seu objeto, pode ser comprovada no texto Mitologias, quando, definindo a narrativa (mítica) como um modelo tridimensional, formado por significante, significado e o próprio signo, afirma que a narrativa em si é apenas uma mera linguagem, e que o sentido mítico - o que se espera desvelado - só será possível a partir da revelação de uma cadeia semiológica primeira, que, evidentemente, encontra-se, como Eco prevê, numa ordem anterior da linguagem, ou seja na esfera do pensamento.

Para a compreensão dos meios de comunicação, na verdade narrativas míticas do ponto de vista em que as concebe Barthes e outros mitólogos, tomaram-se para pressupostos as modernas reflexões compiladas também por Gore $\mathrm{Vidal}^{3}$, em que jornalistas de notório conhecimento discutem as relações entre governo, imprensa e poder para a sustentação de um determinado tipo de ideologia (cuja avaliação de mérito não interessa aqui neste trabalho), para o que narrativas jornalísticas, cinematográficas e televisivas foram ardilosamente montadas à guisa de artifício retórico. Instituições importantes, tais como a $C I A ; F B I$; redes majoritárias de televisão, como a CNN; o Wall Street Journal; Time, New York Times; a era McCarthy e outros veículos de comunicação e poder importantes na América estão arroladas no livro para exemplificação de como

In Into the buzzsaw - Leading juournalists expose de myth of a free press, USA, 2002. 
funciona uma teia de comunicação que interliga todos os elementos do poder em direção à montagem de um edifício ideológico.

Em Judith Lichtenberg ${ }^{4}$ [1990], a análise das tensões entre o princípio da autonomia editorial e o ideal de largo acesso aos meios de comunicação, que foram discutidos do ponto de vista da necessidade das organizações empresariais, foram fundamentais para que as relações das páginas de opinião com o leitor tivessem sido estudadas à luz da análise de falseamento de linguagem estrategicamente montado pela mídia brasileira no objetivo de preservação de um mito político de poder.

\section{Procedimentos Metodológicos}

Para se verificar a hipótese de que a duração, a formatação e a composição da página 7 - Opinião - do jornal $O$ Globo, formalizam indicadores de que esta tipologia responde pela formação de um significado diferente daquele construído por cada jornalista nesta página particular, procederam-se às seguintes operações:

(i) pesquisa histórica da existência desta página nos jornais nacionais desde os seus primórdios;

(ii) estabelecimento de um cotejo possível do surgimento desta tipologia opiniática com os períodos históricos politicamente efervescentes;

(iii) verificação das relações do empresariado midiático com os governos da época analisada.

Em seguida, após a compreensão do sentido histórico que essa categoria Opinião manteve desde os tempos da Corte até os dias atuais, passou-se ao estudo das figuras de autoridade no cenário da mídia brasileira no sentido de verificar o grau de permanência e de vigência dos capitais midiáticos no Brasil.

Assim, os capítulos 1 e 2 da dissertação tratam destas questões específicas e buscam formar um quadro de referência para a análise da significação da página 7 - Opinião - do jornal O Globo - que servirá, por sua vez, de significante referencial da significação que a forma

4 Democracy and mass mídia. Published by Press Syndicate of the University of Cambridge. 
desta página adquirirá na construção significante do texto formado por categorias de abstração em que participam: os próprios jornalistas, a forma dialógica estabelecida na página e o ato ilocucionário da própria empresa. Estudam, ainda, os pressupostos teóricos formulados pela moderna Semiótica contemporânea segundo o quê os mecanismos seriados de significação (Eco: Tratado de Semiótica), de repetibilidade constante e de proximidade de um quadro semântico correlacional estabelecido pela significação formal, possibilitam uma aproximação mais cabal com o sentido do texto formado no terreno movediço das abstrações formais.

No capítulo 3 encontram-se os argumentos para a comprovação da hipótese da existência desses mecanismos formais de composição da página 7 enquanto ferramenta poderosa de controle da opinião pública, que se faz por intermédio do disfarce da impressão democrática pelo fato de nomear um espaço comum para articulação de vozes suposta e diametralmente opostas.

No capítulo 4 verifica-se o rastreamento de tipologias similares (inserções de entradas opiniáticas) de reforço, vigentes na composição universal do jornal, como forma de comprovar o dirigismo da empresa jornalística, especificamente com relação a determinados assuntos. Nesse sentido, todas as formas possíveis de emissão opiniática foram analisadas pelo exercício do cotejo transrelacional de suas formas.

Os capítulos 5, 6 e 7 descrevem os mecanismos semióticos que permitiram configurar o sentido duplo dessa página: aparência do contraditório e opacidade da reafirmação da voz autoral empresarial. Para a compreensão desses mecanismos, rastrearam-se todas as categorias semânticas dos textos do articulista Olavo de Carvalho estabelecem sua condensação em unidades maiores de significação e cotejo com as outras recorrentes nos textos dos outros dois (Luís Fernando Veríssimo e Dom Eugênio Sales), todas devidamente descritas figurativamente em quadros e planilhas explicativas.

Finalizando esse quadro analítico, os capítulos 8 e 9 desvelam a estrutura significante de um metatexto em que a própria página funciona como um significante do texto e da voz empresariais.

No capítulo 10 inscrevem-se as conclusões sobre a hipótese inicialmente formulada, assim esperando ter fornecido uma contribuição para os avanços dos estudos lingüísticos e de sua 
inserção na base estruturante de uma nova ciência: a ciência Semiótica.

Retrospectiva analítica da imprensa

"Quando você tiver seu jornal, poderá escrever como entender. Por enquanto não".

O comércio da informação, pelo menos no mundo ocidental, encontra sua origem já no início da era cristã, com Judas Iscariotes ${ }^{6}$. Esse comércio não sofreu até os dias atuais qualquer interrupção. Ao contrário, recrudesceu e aperfeiçoou suas práticas, sendo hoje considerado, de fato, o subsídio maior ao que se denomina desenvolvimento na civilização contemporânea, apenas para citar dois renomados scholars (Alvin Toffler e Gore Vidal) (assunto de informação, de espionagem e da prática da retenção da patente do conhecimento como fatores prevalentes na formação de superpotências. Portanto, a informação, antes de transmitir conhecimento, já transmite uma possibilidade de contrato comercial em que conhecimento é mercadoria de valor agregado. Frota (1994) ${ }^{7}$ ressalta a distância que separa "a intelectualidade dirigida especialmente para o estudo da incrementação dos setores empresarias, industriais e econômicos daquela que o entende como fenômenos indutores das transformações históricas, aí buscando a compreensão das mentalidades". Na complementação dessa idéia, após ressaltar o surgimento de literaturas técnicas e científicas voltadas para o gerenciamento da informação e de tecnologias voltadas para gestão desta, acrescenta que sua proliferação "já forma um manancial suficiente para que se identifique na informação, especificamente na tecnologia da informação, a motricidade do rito de

5 Resposta que Bogéa, fundador do Jornal Pequeno, recebeu do diretor do jornal de propriedade dos Diários Associados, José Pires de Sabóia Filho, ao tomar conhecimento de que uma matéria sua teria sido censurada.

6 In Bíblia Sagrada, Mateus, 26: 14-16; 14 "Então um dos doze, chamado Judas Iscariotes, foi ter com os principais sacerdotes, 15. E disse: que me quereis dar, e eu vo-lo entregarei? E eles lhe pesaram trinta moedas de prata. 16 e desde então buscava ele oportunidade para o entregar".

7 In Frota. M. H. \& Frota, M. (1994, p.21-22). CNPq/IBICT. Sobre a questão da espionagem tratada por Toffler in Guerra e Anti-Guerra. 
passagem deste para o próximo milênio". Neste sentido, pode-se afirmar que a imprensa hoje adquiriu pela aquisição de alta tecnologia informacional poder infinitamente maior alcançando não o quarto poder, como alguns preferem acreditar, mas o primeiro: aquele decorrente do monopólio informacional. O modelo informativo atual visa, por meio dele próprio, à concentração de poderes, resultando disto a implantação de uma ideologia que, igualmente, se pretende totalitária.

O Renascimento, como período histórico que marcou a volta do conhecimento dos antigos (gregos e latinos) para suporte da mentalidade histórica que haveria de formar-se, privilegia o escoamento desse conhecimento como forma de conduzir o progresso da humanidade.

À medida em que as cidade se desenvolviam, o comércio se alastrava na Europa, onde se pode localizar o foco maior de influência cultural no mundo ocidental. As pessoas necessitavam de informações sobre o que acontecia em suas comunidades e em locais mais afastados, induzindo ao surgimento de um mercado de informação, assim como de seus provedores, no caso os tipógrafos (os primeiros jornalistas), que dependiam de notícias ocasionalmente vindas dos viajantes que lhes permitiam fornir clientes com boletins de notícias a intervalos regulares.

O mercado da informação teria começado a se empresariar quando, em 1622, alguns tipógrafos de Londres, dos Países Baixos e de algumas cidades da Renânia combinaram formar um intercâmbio regular de cartas de notícias, finalmente tornando possível a produção de jornais semanais. A princípio, ocuparam-se principalmente de notícias internacionais, mas, gradualmente, concederam maior espaço à política interna que, no decorrer do tempo, se tornara demasiado complexa para ser compreendida apenas pela narrativa oral. Assim, o momento torna-se propício ao aparecimento de jornais diários, tendo o primeiro deles sido fundado em 1702, por Samuel Buckley: o londrino Daily Courant ${ }^{8}$.

8 CHAPARRO, M. C. observa que o Daily Courant desapareceu em 1735 , mas o modelo por ele criado teria resistido ao tempo. No campo da teoria, afirma que a "experiência criada por Buckley, a cultura jornalística criou 
Está se falando, então, da relação simbiótica ${ }^{9}$ natural entre os três elementos pioneiros - trânsito regular de informação; tipógrafos; viajantes/mascates - com as figuras sociais representativas dessas funções na atualidade: acontecimentos reais, imprensa e meios de comunicação.

Para efeito do entendimento da força desse poder midiático, hoje imperante na conformação das mentalidades, basta, do nosso ponto de vista, uma olhadela na certidão de nascimento dessas categorias supra-históricas que, pelo fato de não terem sofrido solução de continuidade, adquiriram excelência-em-processo-contínuo juntamente com a agregação de valores tecnológicos "apressados".

A ganância capitalista do homem contemporâneo é alvo principal dos debates sobre o futuro político da humanidade, com subsídio em teses "biológicas" do homem enquanto animal predador e naturalmente faminto de poder e bens. Sem a pretensão de aprofundar a validade/invalidade do argumento, tem-se como fato a natureza predatória do homem, que avilta a sua própria natureza através do outro que o assemelha. Nesse processo de aviltamento, o interesse joga papel fundamental. Seja, talvez, por isso que a descoberta do interesse que as notícias, as fofocas provocavam na época dos mascates e viajores, tenha aguçado o apetite financeiro - e posteriormente explorador - dos divulgadores de fatos, transformando uma atividade social, saudável, de certa forma como são as narrativas e fofocas ingênuas dos viajantes sobre as gentes e as fofocas citadinas, em mercadoria altamente rentável e, seguramente, com alta cotação no mercado da informação

Em ordem de importância, o século XVIII trouxe consigo aperfeiçoamentos na técnica de impressão e maior regularidade dos

o paradigma que até hoje divide o jornalismo em Opinião e Informação". In Sotaques d'Aquém e d'Além Mar - Percursos e Gêneros do Jornalismo Português e Brasileiro, Jortejo Edições, Santarém (Portugal), 1998. Para o autor, essa dicotomia teria criado a farsa da objetividade do jornal.

9 Carpentier [1976], em seu romance El Siglo de las luces narra a chegada de um francês Victor Hugues, às Antilhas, com o objetivo de levar os ideais da Revolução. Segundo o autor, o francês traria o fundamental para alcançar tal feito: "levara em seu navio dois instrumentos da nova ordem: a prensa e a guilhotina". 
serviços postais, o que teria aumentado o volume de notícias e a circulação dos jornais. Tendo-se expandido essa atividade, o jornalismo tornou-se, então, uma profissão, ao invés de um exercício secundário de empreendedores tipógrafos, e o jornal passou a fazer parte da vida cotidiana na Europa Ocidental e na América, onde notoriamente se expandiu com maior rapidez e penetração nas massas.

Leve-se em consideração a ressalva de que jornais que exprimiam opiniões independentes ou publicassem fatos que as autoridades desejassem esconder não eram vistos com simpatia por reis e governos. Na maior parte dos países, não podiam ser publicados sem expressa autorização oficial. Mesmo para os governos não ditatoriais, apenas uma minoria culta tinha acesso ao que acontecia na esfera pública de poder, limitando desta forma o acesso às notícias e sua circulação.

Estão aí explicitamente nomeados a função da censura e do privilégio no poder. Formas disfarçadas de censura encontram-se na utilização do "escudo monetário", em que a imposição de altas taxas de imposto sobre mercadoria determina uma seletividade social, que, por sua vez, constitui forma declarada de censura e imposição de poder. Por exemplo, na Inglaterra isso fica patente com a alta taxa de impostos aplicada aos jornais. Em 1815, o jornal The Times londrino, o de maior circulação no mundo, à época, pagava de impostos por cada exemplar, dos $5.000^{10}$ que vendia, o equivalente a aproximadamente $57 \%$ de seu valor.

Mudanças não tardariam a ocorrer. Em meados do século XIX verificaram-se grandes alterações nesse mercado: os impostos sobre os jornais foram abolidos ${ }^{11}$, franqueando a regra da liberdade de expressão e maior acesso à informação. Os jornais ingressaram na era da informação, as notícias passaram a chegar e sair mais rapidamente de suas redações, primeiro pelo telégrafo, e mais tarde pelo telefone. Com isso, o processo de impressão acelerou-se e, transportavam os jornais às cidades e aldeias distantes.

10 In Os Meios de expressão (1969) - Vol. 7. Publicações Europa-América, Portugal.

11 Ob. Cit. 
Com os avanços da era da industrialização e o conseqüente surgimento de meios tecnológicos sofisticados, como o telefone e o telégrafo, que influíram na velocidade da transmissão e na circulação de informações, acelerou-se o processo de impressão bem como, aceleravam-se os comboios de transporte de notícias entre as cidades e aldeias, antes espacial e temporalmente distantes.

Não foi longo o período antes que empresários e industriais conscientizaram-se da função utilitária do jornal como veículo eficaz para venda de produtos, mercadorias e serviços, além de "embutidos e enlatados ideológicos". Como bem se vê, paralelamente ao interesse genuíno pela circulação da informação, nasceu o interesse voraz pela venda de produtos, os mais diversificados, redundando isto na oficialização do que hoje denomina-se propaganda \& marketing, ou publicidade, simplesmente.

Em se considerando a necessidade de se atingir um número cada vez maior de leitores, a questão do nível de linguagem deve ter sido considerada item fundamental nas estratégias de ampliação do contingente leitor que, de certa maneira, acaba influenciando a qualidade, a linguagem e o nível cultural das matérias publicadas. Corroborando esta hipótese, Cândido ${ }^{12}$ já deixava entrever a incapacidade da literatura em acelerar o processo de desenvolvimento político e formação da independência nacional devido não á inexistência de uma literatura capaz disto, ao analfabetismo que inviabiliza o crescimento exponencial do público leitor. Na Inglaterra e na América a publicidade é vista como contribuinte importante para a lucratividade dos jornais. Todos esses fatores colaboraram para que jornais pudessem se produzir em grande escala, reduzindo custos e preço. Rapidamente, então, o cidadão comum passou a ter acesso facilitado a esse veículo, originando-se o ciclo, vigente até hoje, da formação de grandes tradições e crenças em verdades institucionalizadas. Prova disto é a validade do slogan vivo até hoje quanto à corroboração de um argumento contestável: "é verdade, sim. Deu na televisão" ou "no jornal", o que dá no mesmo.

Uma rápida retrospectiva histórica brasileira pode nos ajudar a observar que a Imprensa Brasileira funcionou sob pressão e censura

12 In Educação pela noite: Literatura e Subdesenvolvimento. São Paulo, Ática, 1987, p. 140-162. 
em vários períodos, desde a Chegada da Família Real, passando pelos primeiros generais da República, pela Era Vargas e seu Departamento de Imprensa e Propaganda (DIP), até o período da ditadura militar, para, atualmente, o período da ditadura financeira com a desnacionalização do capital.

Alguns exemplos escapam ao cabresto histórico, aliviando na história da nossa imprensa a servidão absoluta. Do Maranhão vem um exemplo de um jornalista que quebrou o dirigismo patronal: José Ribamar Bogéa, que, tendo iniciado sua vida profissional ainda adolescente sem qualquer tipo de remuneração, passando por vários departamentos até tornar-se profissional nos Diários Associados, ousou discordar da linha editorialista deste jornal, mudando o rumo de sua trajetória jornalística. Depois de oito anos de trabalho nos Diários Associados, quando fazia a cobertura do jogo Moto x Fluminense (RJ), em 1947, criticou, na qualidade de repórter, a atuação do árbitro da partida, Élvio Furtado, um oficial do Exército do Ceará. Censurado, foi reclamar para o diretor do jornal, José Pires de Sabóia Filho, dele recebendo a seguinte resposta: "quando você tiver seu jornal, poderá escrever como entender. Por enquanto não". A partir daí, Bogéa, não sucumbindo à demissão, criou o jornal "O Esporte" mais tarde intitulado "Jornal Pequeno" com primeira edição em 29 de maio de 1951, supondo-se que a partir daí pôde veicular a própria opinião, não se sabendo, no entanto, se manteve os mesmos padrões que o fizeram afastar-se dos Diários Associados.

Quanto à trajetória da censura na imprensa brasileira, dois períodos servem de comprovação irretorquível da predominância da voz da imprensa na sua relação com as forças governamentais: a era Vargas e a chamada ditadura militar.

A Era Vargas fornece subsídios importantes para a questão da promiscuidade entre Governo e Imprensa. Em 1935, Vargas, contendo o crescimento da intentona comunista, impôs estado de sítio e a censura à imprensa. Os jornais de peso ficaram inviabilizados pelo fato de terem seus pedidos de empréstimo a bancos negados, e submissão à censura e corte das propagandas comerciais. No período do Estado Novo, iniciado em 10 de novembro de 1937, houve o recrudescimento dos atos de censura. Nesta fase, os jornais eram censurados e ainda tiveram, por determinação do governo federal, caçadas as concessões para abertura de novos jornais foram vetadas e 
ainda houve o fechamento de alguns jornais. Não sem razão, segundo informação de Morais (2000, p.492), Chateaubriand guardava um olho nas suas atividades empreendedoras e outro na política, que sabia, viabilizaria o primeiro olho. Assim, diz-se que:

quando Getúlio ainda amargada a obscuridade do mandato de senador, obtido três anos antes, ele profetizava em um artigo intitulado "O novo Show" a volta de Vargas à Presidência, para qual os seus jornais iriam contribuir significativamente.

Essa observação é interessante para fomentar a especulação sobre a origem das alianças, muitas vezes incompreensíveis da imprensa com determinado governo. Olhando retrospectivamente para esse episódio de Chatô, pode-se indagar se as eleições de um governo são ou não realmente alavancadas pela imprensa, ou se a imprensa embarca em um apoio a determinada candidatura por saber de seu sucesso antecipado.

De toda forma, a governança, mesmo que artificialmente pacífica conhece o poder da imprensa para uma sustentação política, respeitando-a e com ela formando laços estreitos de convivência ou amordaçando-a sob pena de sanções legais. O DIP, Departamento de Imprensa e Propaganda, foi criado no objetivo explícito de exercer o controle sobre os serviços de imprensa e radiodifusão, criando, em cada estado da federação, o DEI, Departamento Estadual de Imprensa. Ainda nesta época foi criado o DOPS, Departamento de Ordem Política e Social, cujos membros eram policiais com poderes para cercear qualquer iniciativa contrária à política e à ideologia de Vargas. A vigência da censura, "natural" em regimes não democráticos, pode equilibrar as forças do poder constituído. Já em regimes de governo democráticos, outras formas de controle da imprensa e censura são necessárias no caso exemplar para este trabalho, percebe-se que não foi outra a razão pela qual Vargas decidiu-se pelo fomento à criação e fundação de outros jornais como forma de minar a hegemonia da imprensa vigente.

Após o mandato de Gaspar Dutra, Vargas candidatou-se e, em 1951, mais uma vez toma posse. As relações antes difíceis com a imprensa agora se acentuariam. Vargas não dispunha mais do poder absoluto para controlá-la, nem de tempo, pois a situação econômica do 
País, já naquela época, era preocupante, consumindo com ela grande parte do tempo. Mesmo assim, Vargas conseguiu criar um órgão oficioso, de base popular, visando ao enfrentamento dos outros jornais, pertencentes às agências estrangeiras de publicidade.

Foi nesse período que nasceu o império jornalístico de Assis Chateaubriand, fundador dos Diários Associados, erguido às custas de generosos empréstimos do governo. Havia uma relação simbiótica entre Chateaubriand e Vargas, sendo importante registrar que foi durante a era Vargas que seu império jornalístico teve maior força.

Outro exemplo histórico, bem recente, revelador da ciência dos governos sobre a importância da imprensa para a estabilização ou estabilidade de determinado governo pode ser visto durante o regime militar, quando, a partir de 1964, e até 1979, ainda durante a ditadura militar, a imprensa sofreu drásticas transformações quase sempre direcionadas ao cerceamento de matérias e publicações ideologicamente contrárias à filosofia do governo e à abertura da imprensa ao capital internacional.

Nesse período de censura da imprensa durante o governo militar no Brasil, o fato de ter sido alardeado que a distensão para o regime democrático seria lenta e gradual importa para esta pesquisa na medida em que tal promessa redemocratizante veio acompanhada pela modificação da forma jornalística. É desse período, a partir do governo Geisel, que apareceram as primeiras manifestações da abertura, simbolizadas pela criação na formatação jornalística de uma página denominada Opinião. Deste ponto de vista, se a intenção real do governo militar fosse a preservação de um regime absoluto, a página opinião disfarçava, por assim dizer, a farsa da retórica governamental, concedendo hipoteticamente à população o direito da livre manifestação, antes sumariamente censurada ou caçada.

Nesse processo de cooaptação, o elemento lúdico interfere num grau bem mais elevado do que a simples adequação do assunto a ser veiculado com a expectativa ou o desejo ou o interesse imediato e pontual de uma comunidade leitora. A Cinética, a dinâmica, a sonoplastia, a "sonoblastia" têm um apelo forte no imaginário do leitor ou espectador. Não é à toa que alguns jornais majoritários do País passaram, bem recentemente, a reproduzir fotografias elucidativas das principais manchetes na primeira página em cores total, numa tentativa evidente de dinamizar a placidez plana das letras 
impressas, com isso comparando a tese de que as formas, os meios e a formatação influem na semantização de força.

CRONOGRAMA DO NASCIMENTO DAS PÁGINAS OPINIÃO

\begin{tabular}{|c|c|c|c|}
\hline JORNAL & FUNDAÇÃO & $\begin{array}{l}\text { PÁGINA } \\
\text { OPINIÃOO }\end{array}$ & GOVERNO \\
\hline $\begin{array}{l}\text { Folha de São Paulo } \\
\text { (SP) }\end{array}$ & 01/01/1960 & $22 / 06 / 1976$ & $\begin{array}{c}\text { Ernesto Geisel } \\
15.03 .1974 \\
15.03 .1979\end{array}$ \\
\hline $\begin{array}{c}\text { Correio Braziliense } \\
\text { (DF) }\end{array}$ & $\begin{array}{l}\text { a) } 1808 \\
\text { (Londres) } \\
\text { b) } 1960\end{array}$ & 09/03/1977 & $\begin{array}{c}\text { Ernesto Geisel } \\
15.03 .1974 \\
15.03 .1979\end{array}$ \\
\hline $\begin{array}{c}\text { Jornal do Brasil } \\
\qquad(\mathrm{RJ})\end{array}$ & 1891 & $06 / 01 / 1979$ & $\begin{array}{c}\text { Ernesto Geisel } \\
15.03 .1974 \\
15.03 .1979\end{array}$ \\
\hline $\begin{array}{l}\text { O Dia } \\
(\mathrm{RJ})\end{array}$ & 05/06/1951 & 1983 & $\begin{array}{c}\text { João B. Figueiredo } \\
15.03 .1979 \\
15.03 .1985\end{array}$ \\
\hline $\begin{array}{l}\text { O Globo } \\
(\mathrm{RJ})\end{array}$ & 1925 & $12 / 08 / 1990$ & $\begin{array}{c}\text { Fernando Affonso } \\
\text { Collor de Mello } \\
\text { 15/03/1990 e } \\
01 / 10 / 1992\end{array}$ \\
\hline
\end{tabular}

Quadro I - Cronologia das páginas Opinião

No entanto, cabe ressaltar que dados estatísticos de per se não são suficientes para a ratificação de um fenômeno. Assim, a simples tiragem de um jornal pode ser um fraco índice de sua influência política. Se lido e levado a sério por pessoas em posição de destaque, sua influência não guardará relação de proporcionalidade com a tiragem evidenciada na pesquisa. Não se pode descartar a força da voz e dos ouvidos de lideranças, tais que Igreja, mídia, intelligentzia etc.

$O$ invariante, que independe de capacitação técnica para o atingimento competitivo do público é a linguagem. É ela que instrumentaliza a eficácia das idéias, do pensamento como pretexto 
formal apenas, ou como discurso programado para extrapolar a forma linear das idéias. A linguagem enquanto veículo maior de comunicação prevalece sobre todos os outros tipos de informação e de transmissão do conhecimento, pois é ela que, no exercício de sua função originária, garante, em qualquer idioma em que se escreva, o selo da intenção significativa marcada.

Assim, para que se possa contribuir para a compreensão do estágio que o papel da imprensa exerce na formação do imaginário cultural de uma nação, é importante compreender primeiro a natureza de seu meio de expressão, que pressupõe um conglomerado de palavras, vocábulos, significados, signos, em última instância, que escapam à literalidade primeira em que foram criados. Isto porque a imprensa excludentemente trabalha apenas com uma informação dentre as funções da língua: comunicação, informação, expressão. Basicamente, a imprensa tem o dever de informar o leitor sobre fatos e acontecimentos de interesse de uma determinada comunidade. Esta função está umbilicalmente ligada ao direcionamento comunicacional que supõe o outro, supondo, também, a existência de um diálogo abstrato em que o emissor detém o controle da realidade veiculada e, não seria forçado dizer, do âmbito de apreensão do Outro. Evidentemente que a expressão, no sentido linguíístico do termo, deveria contar menos do que existe nas composições artísticas. Enquanto diálogo, que é o sustentáculo maior da existência da imprensa, de uma maneira geral, a polissemia, filosoficamente entendida, vige no âmbito da necessidade/realidade da comunicação em que transitam as idéias. Supõe-se que a imprensa só possa existir na geografia do diálogo. Já pela amplitude do alcance planejado de sua $\mathrm{vOz}$ - um público considerável numericamente - a habilidade lingüística está entre suas tarefas mais árduas: inventar um nível ótimo de alcance comunicativo. Em seu desfavor estão a singularidade da voz (emissão de voz solitária, sem recurso); vigência em um tempo não real e não imediato (a voz é emitida e a resposta, ou não é conhecida, ou sofre a ação de descontinuidade); e ausência do contraditório, ou de eco, características ordinárias no âmbito do diálogo da comunicação ordinária.

Por outro lado, e paradoxalmente, o tipo de comunicação exercido pela imprensa supera a eficiência do diálogo interpessoal, exatamente porque opera fora do campo dialético gravitacional da alteridade, atingindo um número excessivo de dialogadores e 
impondo-se, exatamente pela negativa ao contraditório, à sua fala e à sua voz. Assim, são exatamente suas "dificuldades" que lhe facultam a soberania da voz.

Isto pressupõe o falar de coisas, de assuntos, veicular idéias, manifestar opiniões - as próprias e as alheias - falar de idealizações, realizações e pressuposições que necessitam de um veículo socializado de entendimento, vulgarmente determinado, língua. $O$ mundo ficaria bem simples se o pensamento funcionasse em uma base de engrenagem idêntica para uma determinada comunidade; se as idéias existissem em um número tão reduzido que tornasse menor o número daqueles desconhecidos ou mal apreendidos; se o vocabulário do mundo só fosse possível a partir da leitura de biunivocidades segundo a qual para cada representante gráfico (letra ou conjunto delas) só houvesse um sentido possível. Fazendo uma alusão aos filósofos que trataram da questão da ambiguiidade nas línguas naturais, aspirando criar uma linguagem cujos signos fossem unívocos, assim se manifestou, $\mathrm{Eco}^{13}$ :

estes filósofos todos sonharam em construir uma língua científica que pudesse ser também universal; nenhum, entretanto, afirmou que tal língua substituiria a língua natural.

No entanto, a polissemia existente naturalmente em uma das funções da linguagem - a expressão - é muito mais poderosa, muito mais rica do que todas as letras do mundo possam supor. Neste sentido, a imprensa, que visa a uma comunicação coletiva, que escreve para uma comunidade, sabe que há apenas uma possibilidade de comunicação eficaz: buscar um código de entendimento comum, tendo como primeiro referencial o instituto da língua, e depois, os outros códigos institucionalizados: seja o político, seja o social, seja o religioso, seja o cultural. Essa função de desvio no instrumento lingüístico utilizado pela imprensa caracteriza um dos mecanismos mais potentes do processo de persuasão e de imposição da sua fala.

Desse ponto de vista, compreende-se como a função da imprensa é cumprida: ela precisa instituir uma fala "universal" que fale para um público diversificado. O grande problema que se interpõe

13 In The Search of the perfect language. Blackwell Publisher, 1995,EUA. 
está no princípio da simultaneidade que lhe obriga a prerrogativa de falar ao mesmo tempo para um contingente diferenciado de pessoas, instituindo um diálogo de amplidão absoluta sobre o qual não possui controle quanto à univocidade interpretativa, comparativamente à habilidade e à capacidade do diálogo ordinário controlada pelas seqüência dialógica que se faz no ato mesmo da fala, ou seja, da emissão de uma voz singular (una).

Com isso quer-se enfatizar que a comunicação - base mesma da retórica e de sua função de convencimento - é imanente à função da mídia impressa ou falada, configurando um dado ponderável no estudo das relações de poder travadas entre as vozes da mídia e os ouvidos da comunidade.

Nessa relação de poder estabelecida segundo o princípio da preponderância da voz emissora, entra como fator auxiliar de importância o princípio da visibilidade da voz por meio da qual os significados, as mensagens, as proposições veiculadas adquirem contornos de tal forma nítidos que a substância deles decorrente incide de maneira avassaladora sobre a captação coletiva a tal ponto de impedir seu esquecimento, fato bem mais marcante quando se trata da mídia televisiva. O recente episódio em que supostos marginais de uma facção do mundo do crime do Estado de São Paulo compareceram a um programa televisivo de prestígio - Domingo Legal, de responsabilidade do apresentador Augusto Liberato -, mostra exemplarmente que: o poder de escolha da realidade que será representada para composição da realidade nacional; a constatação de que verdades e mentiras têm igual valor e peso, do ponto de vista da sua correlação com a realidade de fato no mundo discursivo imediato. O fato importante decorrente desse episódio é que, uma vez lançados no ar, esses fatos induzem à formação de uma crença - ou descrença, não importa - transformando-se em matéria opinativa. Fica claro, mais uma vez, para a nossa percepção, que a essência da representação do mundo e das coisas entra pelo funil de compreensão midiática, adquire uma feição própria no sistema linguajeiro da própria mídia e é oferecida como objeto real aos leitores, aos interlocutores, à sociedade. Já por isso é que as notícias, os artigos, os editoriais, as opiniões compõem um representamen, como Eco o entende.

Trazendo Peirce para abono das bases fundacionais de sua teoria Semiótica, Eco, explorando a idéia do Dynamic Object, analisa 
a categoria do representamen como o resultado de um processo em moto continuum de interpretação da realidade objetiva em que a interferência da dinâmica motivacional impede a captura completa da coisa, ela mesma, transformando a própria tentativa de captura desse objeto no próprio objeto. Desta forma, embora não se tenha a pretensão de adivinhar qual seria o Dynamic Object da imprensa e da mídia de uma forma geral, sabe-se com certeza que o sentido formado pela mídia representa um estágio de significação econômica, política e ideológica nessa série em moto continuum de representações que se valida pelo processo continuado da publicação seqüenciada dos periódicos. Neste trabalho, essa importante faceta da teoria Semiótica encontra-se na análise da formatação de alguns jornais majoritários no País, observada nos períodos pré-eleitorais da recente campanha à Presidência da República e naqueles que sucederam à posse do recémempossado Presidente, ou na mudança da formatação da página 7 (Opinião) d' $O$ Globo, da edição online, por exemplo. No primeiro, a franquia à chamada para a opinião do leitor, que dava acesso já no primeiro link, na barra inicial, desapareceu, dificultando, agora, ao leitor, o acesso aos textos dos principais articulistas da página Opinião e das outras matérias opiniáticas; dificuldade esta que se traduz pela formalização de um cadastramento prévio do internauta e fornecimento de todos os seus dados pessoais como condição para o livre acesso ao jornal. No segundo caso, observa-se a saída de um arauto abalizado (Luís Fernando Veríssimo publica seu último texto nessa página de sábado em 28/12/2002, entrando em seu lugar Zuenir Ventura, em 04/01/2003. Nesses casos, muito embora não se possa detectar o driving force que tenha cunhado o sentido de determinada realidade objetiva, pode-se, por outro lado, inferir que considerado o sentido de uma série jornalística, seu representamen não apenas pode ser facilmente detectável, como se transforma na medida mesma da evolução das séries jornalísticas comparadas. É tentador fazer um cotejo das teorias de representação revistas por Eco com alguns textos contidos em Olson ${ }^{14}$ (1997, p.163-169), mais especificamente, Uma história da leitura: do espírito do texto às interpretações do autor: aí contrapõe-se o tipo de representação aceito diferentemente por duas culturas distintas: a cultura judaico-árabe e a cristã, nas quais a

14 Cf. O mundo no papel. David R. Olson. São Paulo: Ática, 1997. 
aceitação da maleabilidade ou não do sentido cunhava a essência dos domínios religiosos separados, querendo a cultura judaica uma abertura interpretativa mais permissiva e propondo a igreja católica uma rigidez de significação mais sólida. Nessa teoria da interpretação, ou hermenêutica da vida dos pios, ressalta-se no artigo a explicação do autor sobre a natureza do "ponto de vista" como formador natural do que, para Eco, seria o representamen. Para isto, ilustra a diferença entre o comportamento das tradições judaica e cristã, citando os versos de Dante (1317, 1973, p. 99):

Quando Israel partiu do Egito, deixando um povo bárbaro pela casa de Jacó, a Judéia foi feita seu santuário, e Israel o seu domínio', Ora, se aquilo para que atentamos for a letra, ele significa a partida dos filhos de Israel no tempo de Moisés; se for no sentido alegórico, fale-se-nos de nossa redenção mediante Cristo; se for no sentido moral, o que significa é a conversão da alma, da dor e da miséria do pecado para o estado de graça; se for o sentido anagógico, refere-se à liberação da alma santificada das amarras da corrupção deste mundo para ganhar a liberdade da glória eterna.

Vê-se claramente aí que não é nova a consciência de que a inferência seja um processo natural na apreensão da ordem do mundo de que preexista à sua representação.

De fato, a idéia de que as palavras são o simulacro da coisa representada permite que se coloquem em suspensão dois conceitos: 0 da validade da representação e o do princípio da veracidade que motivou a escolha no processo de representação. O processo de representação, portanto, não pode ser entendido como a ratificação das não-verdades ou da impossibilidade de resgatá-la, porém, do único processo que confere validade objetiva às coisas e a ordem no mundo de que, por exemplo, os hieróglifos e a escritura antiga são exemplos cabais.

Já não sem razão, no seu livro $O$ mundo no papel, David R. Olson, estudando o processo metonímico para a compreensão dos mitos, representação legítima de um determinado tipo de compreensão da realidade, entende que

signos ou símbolos não só representam objeto ou acontecimento, mas, de fato, contém algumas das 
propriedades do referente - isto é, casos em que não há uma fronteira nítida entre a representação e o que é representado, em particular no que concerne aos símbolos sagrados -, deixaremos de considerar esse comportamento simplesmente incompreensível. Além disso, teremos preparado o terreno para inquirir sobre as condições em que essas distinções passaram a ser feitas sistematicamente. Porque, pelo que entendo, é quando essas distinções são sistematicamente respeitadas que estamos diante do fim do pensamento mágico ou pelo menos do princípio do seu fim.

"Ce n'est pas une pipe", que ele cita, expressão de Magritte anotada sob sua pintura do cachimbo deve, então, significar que a pintura significa uma outra coisa que não se dá ao conhecimento porque pertencente à ordem da inferência singular, que não se dá ao conhecimento. É assim que, estudando o processo metonímico como manifestação parcial da coisa, do dado a confundir-se com ele mesmo no seu todo, pressupõe modelos de representações como um tipo de atividade que estabelece uma "descontinuidade radical entre a coisa e sua representação". Desnecessário dizer que o processo cinde o próprio signo entre sua parte coletiva, social e sua natureza absolutamente individual.

Como tratado anteriormente, a imprensa escrita passeia no mundo de representação viabilizando um tipo marcado de interpretação da realidade para a compreensão de uma determinada comunidade. Já por isso, é de sua função mesma criar um universo real segundo driving forces naturais em séries históricas pontuais. Até aí, enquanto interlocutor dotado de livre arbítrio na capacidade de expressão e comunicação, nada a reparar do ponto de vista da liberdade de expressão. O grande problema que se interpõe entre a subjetividade da expressão e a realidade material dos argumentos dessa expressão nasce do fato de, compulsoriamente, tornar-se um criador de expressões, um criador de fatos, um criador "autorizado" de realidades. (Por autoridade, entende-se aqui, a autorização com base em concessões governamentais de instituir-se porta-voz dessas funções). O segundo problema que se cria decorre da mistificação em torno da sua propalada capacidade de interpretar universalmente os fatos que representam a realidade universal de uma série social historicamente constituída. É essa pretensão que gera, na maioria das 
vezes, o açúcar da mosca. A liberdade de expressão na imprensa é impossível devido à sua natureza concessionária: sendo uma concessão para prestação de serviço público com fins lucrativos, cessa aí a autonomia da palavra, passando ela mesma a ser um representamen de uma outra ordem constituída, no caso a natureza da ordem política. O segundo elemento de constrição decorre da dependência financeira para a sua subsistência que, em última instância, atrela ao seu poder de representação e da ordem da realidade a outra ordem social representada pelos setores empresariais e produtivos que aportam subsídios de monta em troca do veículo das propagandas (hoje conhecidos como propaganda \& marketing), aqui incluindo a propaganda oficial.

Considerando um ciclo histórico do nascimento da imprensa com predominância da voz suprema de reis ditadores, colonizadores etc., caminhando para o processo de aquisição da própria identidade em que pese a liberdade de expressão num contexto histórico de democratização da voz comunitária, despontou o conceito gerador da imprensa livre que impera até os dias de hoje. Essa pretensão, justa e equilibrada com a construção da nova ordem social contemporânea que prevê a garantia de indivíduos e entidades constituídas para o exercício de suas profissões, desembocou na configuração de um tipo de imprensa que inclui a colaboração/participação do leitor e sua voz na polifonia universal da mídia. Tal fato cunhou na sociedade contemporânea a validade maior ou menor de um jornal na dependência do seu espírito democrático de inclusão das vozes sociais.

Estar-se-ia com isso afirmando a impossibilidade de existência de uma imprensa livre? Teoricamente, não; apenas a sua inviabilidade prática. Desse ponto de vista, o que se pode com maior segurança dizer é que ela existiria caso houvesse um fluxo contínuo de apropriação absoluta de realidades universalmente inteligíveis, com a universalidade das vozes regentes do fluxo das matérias, e com um consenso motivacional entre o pensamento empresarial, os jornalistas congregados e a intenção do Estado ou de Governo. Talvez assim poder-se-ia falar em free press. Basta, porém, que a diferença seja evocada - princípio absoluto de formação do mundo e das espécies - e que o limite espacial da geografia jornalística exista, para que a memória lembre essa impossibilidade. 
Um dos fatores de maior constrição na tentativa de criar a free press assenta-se, evidentemente, no fator econômico. De fato, a materialização dessa instituição (imprensa) em empresa, com corpo institucional estabelecido, com ações no mercado, e patrimônio nominal diversificado, não permite sejam expropriadas as palavras, os signos, os sentidos do imaginário desta própria instituição e dos seus acionistas, sem falar na subserviência e compromissos resultantes das ligações "perigosas" estabelecidas entre free press e free government.

De fato, é sintomática a inclusão da voz pública, no espaço geográfico dos jornais, como forma de suavizar o absolutismo do poder imiscuído na imprensa. Não se pode negar a invariância do papel que as forças de poder desempenham na história da imprensa mundial, do que não foge a brasileira. Mesmo não se buscando detectar a matriz institucional que a suporta, como por exemplo, a maçonaria, a comunidade judaica, o Vaticano e outros conglomerados econômicos, é fato que toda forma de governo vem representada na história da imprensa.

Um dos motivos para se acreditar nesse tipo de relação entre o interesse da mídia empresarial e o poder constituído pode ser buscado em dois tipos de fomento existentes no relacionamento governo/imprensa, historicamente verificados ${ }^{15}: 1$ o subsídio concedido pelo governo sob forma do provimento do papel de impressão (a maior parte do papel imprensa era importada com subsídios do governo federal); 2. as relações comerciais, legais, que se estabelecem entre Governo e os meios produtivos midiáticos, como se pode depreender dos termos do recente Decreto $n^{\circ} 4.799$, de 4 de agosto de 2003.

In Lustosa: "Entre a partida de D. João VI para Portugal e a dissolução de nossa primeira Assembléia Constituinte por seu filho D. Pedro I, o Brasil viveu um período de intensas e profundas transformações. Promovidas por uma elite concentrada no sudeste do País, principalmente no Rio de Janeiro e em São Paulo, mas com a força de elementos de São Paulo e de Minas, sofrendo ecos do que acontecia em lugares distantes como Pernambuco e Bahia, dessas transformações foi motor e veículo a imprensa. Aquele curto período de nossa história, quando foram tomadas decisões cujas conseqüiências se espraiam por toda a nossa vida de nação independente, foi o contexto em que política e imprensa se confundiram da forma mais radicall " (2003, p.58-59). 
Neste Decreto estão esclarecidas as pistas que levam à compreensão do relacionamento econômico que é desenvolvido entre forças operantes de determinado Governo e setores empresarias que, sob amparo legal, resta ao abrigo de quaisquer suspeitas de malversação do erário. No caso deste Decreto, em que o excesso de adendos explicativos pontuais, ao invés de prover esclarecimento, obnubila a clareza diretiva das determinações do próprio Decreto, fica claro que as normas legais para ações de comunicação do Governo com a sociedade, compreendendo a imprensa, relações públicas e publicidade de utilidade pública, institucional, mercadológica e legal, vêm para proteger a autonomia do Governo na canalização, a seu próprio juízo somente, das verbas públicas para parceiros econômicos de sua escolha de que é ilustrativo o recente episódio envolvendo o publicitário Duda Mendonça e o Governo Federal.

A respeito da agregação significante deste mesmo assunto, relacionam-se, a título de ilustração, os atos de presidentes da República suspensivos de subsídios então costumeiros, como foi o caso do papel-jornal às empresas jornalísticas de porte. Durante dois períodos históricos, houve fortes alterações destes subsídios. Jânio Quadros (Presidente da República entre 31/01 e 25/08 de 1961), por meio da Instrução Normativa $n^{\circ} 204$, de 13/03/1961 da SUMOC (Superintendência da Moeda e do Crédito, órgão do qual ter-se-ia originado o Banco Central do Brasil), incluiu o corte dos subsídios, dentre outros, à importação do papel-jornal (conforme Instrução Normativa 70, que vigia desde 1953), sintomaticamente deposto logo depois pela ação de "forças ocultas", segundo sua visão. O segundo fato de mesma natureza ocorre durante o governo do presidente Fernando Affonso Collor de Mello (Presidente da República entre 15/03/1990 e 01/10/1992). Por ensejo do Decreto de 05 de setembro de 1991, revoga milhares de outros decretos, dentre os quais aqueles que proviam subsídio à importação do papel destinado à impressão de jornal, como também dos fomentos previstos em dotação orçamentária governamental para a propaganda.

Fica, pois, difícil, senão impossível, imaginar que possa existir em países de capital empresarial escasso, um tipo de independência da imprensa quando seu produto recebe imediato subsídio governamental, e vice-versa, caso em que imprensa e governo podem disputar a condição de produto de mercado. Não bastasse isso, esse poder paralelo desempenhado pela imprensa encontra respaldo na 
própria Constituição Federal, que favorece a relação simbiótica ${ }^{16}$ entre Estado e imprensa. Inscreve-se na própria Constituição da República Federativa do Brasil, um dispositivo não-tributativo para o caso de empresas que se dediquem à promoção é à divulgação da cultura e da educação nacionais, do que se beneficiam as empresas midiáticas de concessão governamental que desenvolvem projetos desse jaez:

Art. 150. Sem prejuízo de outras garantias asseguradas ao contribuinte, é vedado à União, aos Estados, ao Distrito Federal e aos Municípios:

(...)

VI - instituir impostos sobre (...)

d) livros, jornais, periódicos e o papel destinado a sua impressão.

Conclusão

A página Opinião, que reflete um aparente equilíbrio de forças entre supostos dialogistas não mudou sua configuração e sua intenção de instituir-se voz universal desde seu aparecimento na imprensa reinol, no Brasil.

A cultura de simbiose da imprensa com o poder instituído vem com a formação política da nação brasileira.

O exemplo da Carta de Privilégio aos Impressores, de 20 de fevereiro de 1508 (anexo XV), mostra a estreita proximidade que a imprensa e a igreja mantêm com os poderes instituídos e os misteres governamentais as mesmas que imperam ainda hoje não obstante algumas rupturas diacrônicas, direcionando para o estado embrionário de formação de uma casta social, ainda vigente, acostumada aos privilégios oriundos da proximidade com o poder, seja na sua versão laica, seja naquela clerical.

16 Esta relação simbiótica, no caso d' O Globo, vai além do que poder-se-ia supor, pois conforme Chiarini (2002, p.169), discorrendo acerca das reformas de $O$ Globo e do Correio Braziliense, e ao modo como esses jornais teriam resolvido reinventar-se, afirma que " $O$ Globo coloca ramais de seu telefone em locais de grande produção de notícias, como a Câmara dos Deputados, o Ministério da Fazenda e o Banco Central". 
Dom Pedro I, a título de defesa ou detração de desafetos políticos, publicava, com vários pseudônimos, nas seç̃es "Cartas à redação", artigos auto-laudatórios em sua defesa, sinalizando para essa união entre a imprensa e o governo com vistas à manutenção do poder [Lustosa: 2003: 30-38]. Vem de longa data o conhecimento de que essa relação estrutura uma via comercial de mão dupla em que comprador e vendedor se alternam ao sabor das conveniências.

Lange e parole, esses dois processos que possibilitam a comunicação humana, se analisados sob a ótica social institucionalizada, correspondem, grosso modo, à necessidade de ordenação da coletividade (lange) para que se libere a identidade individual (parole). Da mesma forma que, fora do anarquismo, deve prevalecer um código civil e jurídico que, cerceando a liberdade infinita dos atos sociais, libera o indivíduo para a existência com o outro, quando só a partir daí o reconhece como igual, assim a langue, enquanto instituição lingüística, atua como um corpo de leis que, cerceando e tolhendo as potencialidades infinitas de comunicação e expressão, legitima a fala individual.

Poder-se-ia dizer que o nascimento da liberdade da fala individual depende de um sistema convencionado e, portanto, legitimamente autorizado; ou seja, a "fala de autoridade", que é sistemática, nasce da própria necessidade de ordenar os mundos subjetivos de expressão e comunicação para que se estabeleça, por princípio, a viabilidade de troca comunicacional por divergência ou por concordância mesmo no concerto polifônico das paroles. Portanto, nenhuma razão pode sustentar o entendimento de que a submissão da parole à langue possa ferir o princípio da autonomia prevalente nas línguas enquanto instituições. O que macula o princípio gerador da liberdade da fala é, ao contrário, a submissão a uma fala hegemônica, imposta por intermédio de mecanismos de cerceamento não-naturais ao corpo lingüístico, como, por exemplo, o determinismo econômico de uma nação sobre a outra; o monopólio dos meios de comunicação e de divulgação artística, cultural e lingüística; o controle do mundo editorial; a hegemonia no controle das tecnologias da informação etc. No caso da palavra opinião, a transformação de uma simples subjetividade em ordem legitimada por alguma forma de imposição é que determina seu caráter impositivo sua transformação em instrumento de poder. Ou seja, transforma, no caso da opinião aqui 
estudada, a opinião do leitor (individual) em opinião da fala autorizada (empresa jornalística) conforme [Perelman] $^{17}$, de quem detém seus canais de produção e divulgação, como anteriormente demonstrado.

Em princípio, na página 06, seção Cartas de Leitores, do jornal $O$ Globo, há uma aparente pluralidade de opiniões e de direcionamento temático, o que caracterizaria realmente a entrada da voz plural na configuração do jornal. Normalmente, o número de entradas de cartas nesta seção (i) varia entre quatorze e vinte e duas, e (ii) apresenta diversidade de assuntos, reforçando, pelo princípio da descontinuidade significante (PRATT, 1978) a impossibilidade de fixação temática imediata. Desta forma, assim concebida, esta página contrapor-se-ia à concepção política da página 7 (Opinião do jornal, aos sábados) que, (i) mantendo constante o número das entradas (são invariavelmente três artigos), reduz a possibilidade de dispersão dos significados e (ii) quantifica o contraditório de significados em apenas três opiniões, fato que já por si caracterizaria uma desvantagem argumentativa com relação ao espírito democrático da página 6 . No entanto, tal crença nesta desvantagem anula-se, tão logo se procede à análise estatística do quantitativo dos alvos das cartas. Tal análise, com relação ao rastreamento dessa repetibilidade, mostra, ao inverso, que a diversidade se rarefaz: das 30 páginas $n^{\circ} 6$, num total de 542 cartas publicadas, $80 \%$ referenciam questões políticas envolvendo as 3 esferas de governo, com predominância das críticas ferrenhas ao Governo Federal - $41 \%$ - (cujo partido político lançara o candidato de oposição ao PT); 27\%, ao governo do estado do Rio de Janeiro, cujo titular (o governador Garotinho, no cargo, em período anterior à sua francamente favorável ao candidato do PT, assim sutilmente marcando a referencialidade semântica que, disfarçadamente, se pretendia realmente consolidar. Evidentemente, tais fatos analíticos tese do artificialismo da página Opinião enquanto arauto da voz democrática: o apoio explícito desse órgão de imprensa ao candidato do PT, cujas razões, econômicas, ideológicas, políticas que possam ser, não cabem no escopo desta análise, que se pretende apenas

17 Tratado da Argumentação (1996). 
Semiótica. Caso contrário, seria necessário proceder-se à pesquisa dos possíveis compromissos firmados entre o candidato vitorioso e as organizações "globais" para que se provasse a interferência decisiva, ou não, dessa empresa midiática na formação do imaginário nacional com aval das próprias forças políticas de ocupação do poder.

A existência das páginas de participação do leitor tem o efeito imediato de capturar sua fidelidade a determinado jornal e à determinada página, nisto criando um mecanismo poderoso de aproveitamento deste espaço para veículo de idéias de reforço ou de motivação direcionada. É sintomática a formatação estrutural das duas páginas analisadas no âmbito deste trabalho: a da página 6, conformando (i) um tipo de narrativa seriada, ao estilo das novelas televisionadas, em que o elemento tensão (manutenção do suspense) gerado mantém cativos a curiosidade e o interesse do espectador, e (ii) provocando, nesse tipo estrutural, o surgimento de temas que alimentam o apetite natural pelo gossiping, assim mantendo determinado assunto na pauta do dia das conversações rotineiras.

A página 7 , Opinião, estabelece um diálogo acirrado, uma polêmica, um contencioso entre escritores, visando à tomada invariável de posição por parte dos leitores e posterior manutenção dessa polêmica para além do momento da leitura, o que consolida a fixação de determinado tema ou idéias que se queiram predominantes. Pequena pesquisa realizada a título de comprovação dessas hipóteses revelou que dois entre dez leitores do jornal $O$ Globo, não "pulam a cerca" das seções, percorrendo um caminho de uma leitura direcional e imotivada. No caso da morte do jornalista Tim Lopes (pág. 6, de 21 de junho de 2002), por exemplo, verificou-se um enxerto absoluto de opiniões sobre a matéria, o que, não obstante a plausibilidade de existência real de um universo de cartas francamente favorável ao assunto, não se pode descurar que o episódio favorecia também o seu aproveitamento como mote à crítica ao Governo e à corporação da Polícia Militar à época sob a mira cerrada do mesmo jornal. A universalidade de opiniões na página 6 relativas ao mesmo assunto, neste caso o conglomerado de cartas de idêntico teor, acaba, ela mesma, se transformando em um claro editorial.

A página Opinião, portanto, define-se como uma forma estratégica altamente eficaz de convencimento do liberalismo democrático da empresa jornalística, escamoteando seu caráter totalitário. 
Sua contraposição à forma editorial, espaço declaradamente marcado para emissão aberta da opinião dos proprietários, democratiza esse espaço, esmaecendo, por seu intermédio, a oposição cerrada que predomina entre a força da voz do poder privado comparativamente a do público.

O breve estudo da história e do desenvolvimento da imprensa no Brasil revelou que são constantes as relações endógenas entre o poder político e o capital mantidas pelo monopólio da fala midiática. A história do sucesso empresarial jornalístico, seja por intermédio da empreitada de Hipólito da Costa para vencer o monopólio opiniático da Corte, seja do império jornalístico montado por Assis Chateaubriand, facilitado pelas relações íntimas de poder mantidas desde Vargas, passando por Dutra, Juscelino Kubitschek e Jânio Quadros, até sua morte em 1968; seja pelo segundo império criado pela família Marinho e até hoje mantido incólume na sua hegemonia, todos, sem exceção, mantiveram-se graças a uma fórmula de autosustentação mútua. O fato episódico histórico envolvendo Manzon, Chateaubriand e Dutra é revelador. Conta Morais [2000: 470] que, tendo composto uma reportagem bombástica, conseguida a custa de exposição a risco de vida, Manzon ofereceu-a para publicação, como de costume, a Chateaubriand que, ve:ificando o teor bombástico da reportagem (fotos da elite da República flagrada em plena atividade ilegal de jogatina no Cassino da Urca, quando o jogo era considerado contravenção), Chateaubriand nega-se a publicá-la exatamente porque mantinha relações de dependência com várias figuras da República. A finalização deste episódio também revela o tipo de relação endógena entre a imprensa e o poder aqui discutida: Manzon oferece essa mesma matéria a Roberto Marinho, que disputava com Chatô a hegemonia da comunicação nacional. Marinho, mesmo afirmando ser a matéria "glicerina pura", compra-a e publica-a, algum tempo depois, sob forma fasciculada, certamente na medida da capacidade de pressão que essas reportagens poderiam exercer em seu benefício.

Com o avanço histórico do processo de redemocratização das relações das massas sociais, fenômeno que vem ocorrendo no mundo inteiro, surge a necessidade de reformulação da estrutura jornalística, aí incluindo, a título de exibição colaboracionista nesse processo, uma forma estruturante que pudesse conter a voz pública: é o momento do nascimento definitivo do espaço opiniático sob os mais diferenciados formatos. 
É notório que todos os jornais do País mantenham um espaço chamado opinião. No entanto, como já se analisou, o controle da emissão dessa voz, feito pela própria empresa jornalística, lhe garante também o controle sobre os temas, assuntos e conteúdos, conformando, portanto, o tipo de voz a ser liberado. Ou seja: essas páginas opiniáticas instituem-se mais como uma forma do que um significado de real concessão às liberdades e ao espaço num regime político democrático. É mero significante, cujo significado varia em função do foco de interesse circunstancial do Poder.

O tempo da liberdade ainda está por ser construído, longe, muito longe do edifício midiático.

Referências

ARISTÓTELES. A arte retórica. Rio de Janeiro: Ediouro, 1985.

BALZAC H. Ilusões perdidas. São Paulo: Abril Cultural, 1978.

BARTHES, R. Elementos de Semiologia. 4a. ed. São Paulo: Cultrix, 1964.

BARTHES, R. Mitologias. $10^{\mathrm{a}}$ ed. Rio de Janeiro: Ed. Bertrand Brasil, 1999:

BARTHES, R. Lição. Portugal: Edições 70, 1988.

CÂNDIDO, A. Literatura e sociedade. $7^{\mathrm{a}}$ ed. São Paulo: Companhia Editora Nacional, 1985.

CÂNDIDO, A. Educação pela noite: Literatura e subdesenvolvimento. São Paulo: Ática, 1987.

CARPENTIER. A. O Século das luzes. Rio de Janeiro: Ed. Labor do Brasil, 1976.

CHAPARRO, C. Sotaques d'aquém e d'além mar. Percursos e gêneros do jornalismo português e brasileiro. Portugal: Jortejo Edições, 1998.

CHOMSKY, N. Segredos, mentiras e democracia. Brasília: Ed. UnB, 1999.

CHOMSKY, N et ali. Manipulação do público. São Paulo: Ed. Futura, 2003.

CRYSTAL, D. Language ant the Internet. Cambridge. U.S.A, 2001

ECO, U. Tratado geral de semiótica. São Paulo: Perspectiva, 1980. 
ECO, U. The Search to de perfect language. EUA.: Blackwell Publish, 1995.

ECO, U. Semiótica e filosofia da linguagem. Portugal: Instituto Piaget, 1984.

ECO, U.. Sugli Specchi. Mirão: Editora Bompiano, 1998.

FROTA, M. H. A. \& FROTA, M. Acesso à informação: estratégia para a competitividade. Brasília: CNPq/IBICT, 1994.

HABERMAS, J. On the pragmatics of communication. Edited by Malve Cooke. EUA. Massachussetts Institute of Tecnology, 1998.

HOUAISS, A. Dicionário Eletrônico da Língua Portuguesa. Rio de Janeiro: Objetiva, 2002.

LICHTENBERG, J. Democracy and mass mídia. Published by Press Syndicate of the University of Cambridge.1990

KITTAY, E. F. Metaphor: Its Cognitive Force and Linguistic Structure. N. Y.: Claredon Press, 1987.

LUSTOSA, I. O nascimento da imprensa no Brasil. Rio de Janeiro: Jorge Zahar, 2003.

MAQUIAVEL, O Príncipe (comentado por Napoleão Bonaparte). São Paulo: Ed. Martin Claret, 2002.

MARQUES DE MELO, J. Jornalismo Opinativo. São Paulo: Ed. Mantiqueira, 2003.

MORAIS, F. Chatô o Rei do Brasil. São Paulo: Companhia das Letras, 2000.

OLSON, D. O mundo no papel. São Paulo: Ática, 1997.

PEIRCE, C. S. A Ciência da Semiótica. São Paulo: Perspectiva, 1974.

PEIRCE, C. S Semiótica. São Paulo: Perspectiva, 2002.

PERELMAN, C. Tratado da argumentação: a nova retórica. São Paulo: Ed. Martins Fontes, 1996.

VIDAL. G. Into the buzzsaw - leading journalists expose de myth of a free press. USA, 2002.

WERNECK SODRÉ, N. História da Imprensa no Brasil. 4a.ed. Rio de Janeiro: Ed. Mauad, 1998. 